\title{
CHARLES MASON'S INFLUENCE ON IOWA JURISPRUDENCE
}

\author{
By Willard I. Toussaint
}

Charles Aldrich, a noted curator of the Iowa State Department of History and Archives, was once asked to name the two greatest men in Iowa's history. He chose former governor Charles W. Grimes and Charles Mason, first Chief Justice of the Iowa Territorial Supreme Court. If others were likewise asked to select Iowa's foremost historical figures, there would certainly be a wide difference of opinion; but there can be no doubt that Charles Mason was a prominent business and civic leader in the State's early history. ${ }^{1}$ For more than 40 years he was an outstanding figure in judicial, political, and business affairs. ${ }^{2}$ It is to the period of Mason's judicial career in Iowa, 1838-1851, that the present study relates.

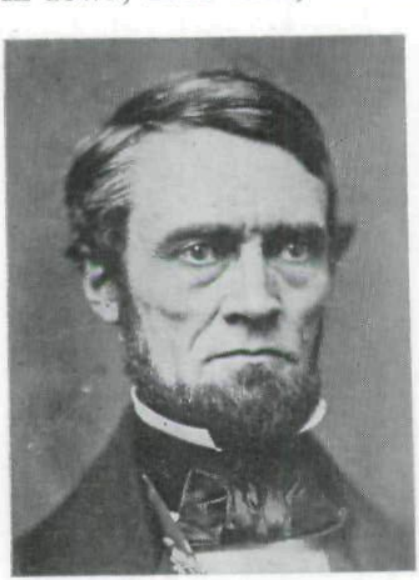

Charles Mason

A native New Yorker, Mason had graduated from West Point in 1829 , then resigned his commistion to practice law briefly in the East before coming to Iowa in 1837. After settling in Burlington, he was district attorney in Des Moines and Van Buren counties while Iowa was still part of Wisconsin Territory. In 1838 he was appointed by President Martin Van Buren to be Chief Justice of the newly formed Iowa Territory. He held this position nine years, from July, 1838, to May, 1847. During this time, Mason helped the legislature formulate statutes under which the judiciary was to function. After Mason left the Supreme Court, the Iowa legislature selected

${ }^{1}$ Edward Stiles, Recollections and Sketches of Notable Lawyers and Public Men of Early Iowa (Des Moines, 1916), p. 19.

${ }^{2}$ George Wright, "The Yewell Portrait of Charles Mason," Annals of Iowa, Third Series, II ( July, 1895), 164. 
him to be one of three commissioners to prepare a state law code, which was adopted in 1851. For the next four years he was United State Commissioner of Patents; and from the expiration of this term of service until he died in 1882 he was actively engaged in the management of various important financial enterprises in Iowa. ${ }^{3}$

An analysis of Mason's legal decisions as Supreme Court justice raises the question of whether any general trend can be discerned in them. If so, the fact is significant because it suggests that one Supreme Court jurist left the pattern of his legal and economic views on early Iowa jurisprudence. This observation becomes even more significant if it is sustained in Mason's other legal work, in collaboration with the legislature, and later in the codification of Iowa law. The analysis also points out the nature and extent of Mason's influence on the formulation of Iowa law. During the years of his service on the bench, he heard and determined questions of great importance and established precedents which the courts have followed ever since. The work of the Territorial Supreme Court, then, was very important in that it gave form and direction to all future state law. ${ }^{4}$

One should judge Mason's contributions to Iowa law in the light of his limited legal training and experience before coming west. In his summer vacations, while still at West Point, he had begun to read law. After the close of his military career, he entered the law office of a New York attorney, where he read law for a year, passed the bar examinations in June, 1832, and was admitted to practice in New York State. In the fall of that year he moved to Newburgh-on-the-Hudson, where he practiced law for two years. In 1834 he returned to practice in New York City. ${ }^{5}$ Thus his legal experience before settling in the West in 1837 totalled only five years.

Another factor to be noted before assessing Mason's judicial contributions to his adopted state is that he had evi-

\footnotetext{
${ }^{3}$ Emlin M'Clain, "Charles Mason-Iowa's First Judist," Annals of Iowa, Third Series, IV (Jan. 1901), 598.

${ }^{4}$ Wright, "The Yewell Portrait," p. 171.

${ }^{5}$ Charles Remey, Life and Letters of Charles Mason (16 vols., Washington, D. C., 1939, I, 43.
} 
dently formulated his legal philosophy before coming west. His diary notes indicate disillusionment with the way law was practiced in New York. In comparing court procedure in the East with what he had observed in the West, he wrote:

I like the course of judicial proceedings here much better than in our state. Legal quibbles here meet with much less consideration than in our courts, and justice does not so frequently fall a victim of chicanery and technical formality. The deviation of a word of phrase of mere form does not so shock the fastidious ear of justice as to cause her to deny the injured but unfortunate wretch a hearing. ${ }^{6}$

Thus early in Mason's legal career he indicated preference for court rulings based on what seemed obvious justice rather than strict adherence to judicial form.

Mason made a start in public life shortly after coming west. He spent the winter of 1836-1837 in Belmont, capital of Wisconsin Territory, of which Iowa was then a part. ${ }^{7}$ The capital was temporarily moved to Burlington while preparations were made for reception of the legislature in Madison, which was to be the permanent seat of government. That part of Wisconsin Territory west of the Mississippi was constituted the third judicial district and David Irvin, one of the federal judges, was assigned to it. When Judge Irvin decided to make Burlington his home, Mason accompanied him there in February, $1837 .^{8}$ Two monthers later, Governor Henry Dodge of Wisconsin Territory appointed Mason the public prosecutor of Des Moines county, a post he filled until April, 1838. When the Wisconsin legislature created several new counties, Mason was made temporary district attorney for Van Buren county. ${ }^{9}$ Thus in spite of Mason's lack of extensive legal training or experience, he found himself launched on a public career at the frontier.

After Iowa became a separate territory in June, 1838, President Van Buren appointed Mason as Chief Justice of

${ }^{6}$ Charles Mason Diary, August 5, 1836, in Mason Collected Papers and Diaries, Iowa State Department of History and Archives, Des Moines, Vol. 46.

${ }^{7}$ Jacob Swisher, “A Just Man," Palimpsest, XIX (Iowa State Historical Society, Sept. 1938), p. 361.

${ }^{8}$ Swisher, "Judiciary of the Territory of Iowa," Iowa Journal of History and Politics, XX (April, 1922), 245.

${ }^{9}$ Remey, Life and Letters of Charles Mason, I, 78. 
the Territorial Supreme Court. As Mason's associates on the bench, the President appointed Joseph Williams of Muscatine and Thomas S. Wilson of Dubuque. However, in the nine-year period during which Mason served as Chief Justice, his influence must have been predominant not only in the labors but in the judgments of the tribunal. In the Territorial period from 1838-1846 the court decided 191 cases, and in only 25 of these did the other two judges write opinions. ${ }^{10}$

The large share of legal business over which Mason presided on the district level gave him additional opportunity to express his judicial philosophy during the court proceedings of the Territory. During the time that the three judges sat on the bench they functioned within a judicial system which divided the Territory into three judicial districts. Each Supreme Court Justice was assigned to a district court; and when cases were appealed, the three justice would constitute the highest tribunal. Mason was assigned to the first judicial district, composed of the two southern tiers of counties. In the eight years of the Territory this area contained more than half the population; as a result, a proportionately large share of the legal business was transacted there. ${ }^{11}$ Moreover, there were occasions on which the Chief Justice not only presided over his own judicial district but that of his associates as well. Dubuque, Cedar, and Jackson counties were in the judicial district assigned to Justice Wilson; but because cases were pending in which Wilson had been retained as counsel, Chief Justice Mason presided over the first courts held in Dubuque and Jackson counties. ${ }^{12}$

Some cases which came before the Supreme Court are noteworthy because they illustrate Mason's unwillingness to allow legal technicalities to negate apparent justice. In cases involving law and order, for example, he frequently refused to allow legal minutiae to obscure the real intent of the law. In Indian v. Teagarden he refused the appeal of a murder conviction in which the defendant contended that the verdict was invalid because the jury was not lawfully and properly

${ }^{10}$ M'Clain, “Charles Mason-Iowa's First Jurist,” p. 598.

${ }^{11}$ Letter of Charles Mason to Edward Stiles, Jan. 23, 1882, in Stiles, Recollections, p. 25.

${ }^{12}$ Swisher, "A Just Man," p. 358. 
sworn. In this case the jury had convicted an Indian of murdering a white man; subsequently the defendant carried the case to the territorial Supreme Court. Mason held that he could not sustain such an objection after the case had gone to trial and the jury had rendered a verdict. In reading the decision, Mason said:

The proceedings below will be presumed to have been correct unless the contrary is shown by the plaintiff. . . . It would be subversive of justice to allow a party to remain silent in relation to matters of this nature until after the final hearing, and then obtain a rehearing of the case and put the public to the trouble and expense of a new trial, merely because a clerk of the district court omitted a caption to his transcript. ${ }^{13}$

In the case of Hight and Hight v. the United States Mason followed the same general philosophy of not allowing legal form to take precedence over justice. George W. Hight and George V. Hight had been indicted upon charge of murder. They subsequently brought action on a writ of habeas corpus for purpose of being admitted to bail. It was contended for them that evidence against them before the grand jury was so slight that they were entitled to be released on bail. When the district court refused to bail the prisoners, their lawyer appealed the case to the Supreme Court. Chief Justice Mason ruled that while an indictment furnishes no presumption of guilt against a defendant on trial, it furnishes strong presumption of guilt in all proceedings between indictment and trial. He declared that although it is within the power of the court to grant bail, a defendant cannot in capital offenses demand bail as a natural right. Mason ruled that the court was not required to investigate the evidence upon which indictment is found, and that findings of a grand jury are conclusive against the prisoner, although they may have been found on slight evidence. ${ }^{14}$

There were other cases in which Judge Mason was unwilling to see legal formality used as a weapon against a defendant. In Edward Powell v, the United States Mason ruled that it is not necessary that a defendant plead, the presump-

\footnotetext{
${ }^{13}$ Indian v. Teagarden in Easton Morris (ed.), Reports of Cases Argued and Determined in the Supreme Court of Iowa, I, 335. 407.

${ }^{14}$ Hight and Hight v. United States in Morris (ed), Iowa Reports, I,
} 
tion being that he would plead not guilty. In this instance the court gave the defendant benefit of the doubt without insisting on a technicality. ${ }^{15}$ Likewise in Harrell $v$. Stringfield Mason ruled that technical phraseology in the verdict was not material and that an error which could do no harm was insufficient to justify a reversal of judgment. ${ }^{16}$ Mason was willing to allow form to have its way only when it did not obstruct justice. Thus in Gordon and Washburn v. Higley Mason ruled that a district court could direct such change in a jury's verdict as to make it correspond to usual forms whenever such change could not by any possibility alter the evident meaning of the verdict. ${ }^{17}$

Chief Justice Mason also put obvious justice before technicalities in cases involving debt. An instance of this kind with respect to debt was Mason's refusal of appeal by Robert Lucas on a writ of error. A suit had been brought in the district court of Muscatine county against Robert Lucas for payment of a promissory note. A sheriff had served notice of the suit, leaving a copy of the writ at the home of Charles Nealley, referred to in the legal paper as "the usual place of residence" of Robert Lucas. At that time, however, Lucas was living elsewhere, and defended the suit on the ground that he had not been properly served with notice. The district court held otherwise. When Lucas appealed to the Supreme Court, Mason ruled that there was no ground for complaint against the ruling of the lower court, and that if injustice had been done Mr. Lucas, his remedy was in equity. ${ }^{18}$

Several notable cases involving property also illustrate Judge Mason's prevailing principle of giving more consideration to apparent justice rather than to legal details. The case of Swan v. Catham bears out this point. Chauncey Swan of Iowa City sold Lot 4 in Block 97 to John Ewing and James Catham. They paid one-fourth of the purchase price, and gave three promissory notes, each for the same sum, in payment of the balance. The certificate of purchase, through

${ }^{15}$ Powell v. United States in Morris (ed.), Iowa Reports, I, 13.

${ }^{16}$ Harrell v. Stringfield in Morris (ed.), Iowa Reports, I, 18; 335.

${ }^{17}$ Gordon and Washburn v. Higley in Morris (ed.), Iowa Reports, I. 13.

${ }^{18}$ Swisher, "Iowa in 1844," Palimpsest, XXV (Iowa State Historical Society, May, 1944), 150-151. 
error, was made out for Lot 3 instead of Lot 4. Later, Swan sold Lot 4 to another party. When the notes fell due, Ewing and Catham refused payment. The local court directed that the advance purchase money be refunded, and the Supreme Court affirmed the decision. ${ }^{19}$

In Hughell v. Wilson the Supreme Court again protected rights by giving greater preponderance to the spirit rather than the letter of the law. The Territorial Legislature had passed an act providing that the claimant of public lands who had designated his claim but not enclosed it with a fence could maintain an action of trespass upon the claim. The Supreme Court held that the statute was valid and that anybody cutting trees upon such a claim was subject to a fine, even though the claim holder had no legal title from the federal government and was himself a trespasser. ${ }^{20}$

Indeed, in Mason's notable decision in Hill v. Smith he carried independence of the letter of the law even to the point of defending individual property rights against claims of the national government. In March, 1807, Congress had passed a law aimed at pioneers who settled upon the public domain in advance of the surveyor and the land office auctioneer. The law provided that settlers on public lands without right previously acquired from or recognized by the United States should be subject to forfeiture of all rights in such land and removal by the marshal The question was how such squatters on public domain could be made secure in possession of their claims until such time as the government gave them title. How could such settlers prevent the government from selling their land and improvements to someone else? ${ }^{21}$

It is obvious that this federal statute of 1807 was opposed to the ambitions of the pioneers. To protect their improvements and retain the soil they had cleared, the settlers formed "claim clubs" or "claim associations" which were designed to frustrate the land speculator and the competitive bidder who

${ }^{19} \mathrm{Ibid}$., p. 151.

${ }^{20}$ Hughell v. Wilson in Morris (ed.), Iowa Reports, I, 385.

${ }^{21}$ Jesse Macy, "Institutional Beginnings in a Western State," Johns Hopkins Studies in Historical and Political Science, Second Series, VII (July, 1884), 11. 
came to secure title at the time of the land sale. These organizations differed in minor details, but in general they had the same purpose, that of mutual protection of land claims. The clubs gave deeds and recorded them. Squatters could sell claims only when the organizations approved, and the buyer assumed all obligations of the original occupant. ${ }^{22}$

The first legislative assembly of Iowa Territory undertook to define further the legal rights of these settlers. On June 15,1838 , the governor had approved an act providing that squatters on federal land could use it as collateral for all notes or contracts. The creditor could sue the squatter and recover damages as in other contracts where the grantor had the title to the land. ${ }^{23}$ Whether this Territorial enactment was contrary to the United States statutes was not at once clear.

In 1840 the Supreme Court of the Territory interpreted the law in the case of Enoch S. Hill v. John Smith and others. Hill had signed a note promising to pay $\$ 1,000$ in one year to John Smith and Brothers of St. Louis. The collateral for the note was a claim "or the possessory right to a certain tract or parcel of land belonging to the United States." Afterward, Hill argued that the contract was void and the note illegal because it was given for a claim to United States lands in violation of several acts of Congress. ${ }^{24}$

When this case came before the Supreme Court of the Territory, Chief Justice Mason held the contract to be valid, the $\$ 1,000$ recoverable, and in addition Smith was granted $\$ 63.83$ damages. He based his decision not simply on legal precedent in Wisconsin law, of which the Iowa law was a copy, ${ }^{25}$ but on social necessity. The court concerned itself with the effect upon the welfare of the people which would result from holding such transactions illegal. Mason said that public peace dictated need for some better means of enforcing land claims than a bludgeon or a rifle. Hence the legislate had declared that Territorial law should validate contracts rather than that violence and anarchy should overwhelm the

${ }^{22}$ J. T. Johnson, "Pioneers and Preemption," Palimpsest, XXII, (Iowa State Historical Society, Sept. 1941), 257.

${ }^{23}$ Ibid., p. 266.

${ }^{24} \mathrm{Hill}$ v. Smith and others in Morris (ed.), Iowa Reports, I, 70.

${ }^{25}$ Johnson, "Pioneers and Preemption," p. 266. 
whole area. Said Justice Mason:

We believe that in so doing they were not only promoting the public welfare but that they were within their legislative province, and that the law, therefore, for this purpose is valid and binding. ${ }^{2 B}$

Moreover, Mason ruled that the action of the Iowa legislature with respect to land claims was valid because long disuse of the federal statute of 1807 had induced a reasonable belief that it was no longer in force. Could the settlers, Mason asked, be liable to fine and six months' imprisonment for violating a law of which most of them where ignorant and which had not been enforced for more than 30 years, ever since its enactment? He answered that it was contrary to the spirit of our institutions to revive, without notice, a penal statute grown obsolete by disuse, especially when the general current of legislation showed that the legislature regarded the statute as no longer in force. Mason supported this contention by an illusion to two English officials, Empson and Dudley, who during the reign of King Henry VIII were executed because they carried out too rigidly some obsolete and forgotten laws. Mason concluded his opinion by saying:

Fortified by this authority we pronounce it contrary to the spirit of Anglo-Saxon liberty, which we inherit, to revive without notice an obsolete statute, one in relation to which long disuse and a contrary policy had induced a reasonable belief that it was no longer in force. ${ }^{27}$

Mason was contending that a custom of 30 years could repeal a statute, an argument not likely to appeal to the strict legalist but consistent with Mason's usual appeal to circumstances and common sense.

Justice Mason and his two colleagues demonstrated a similar legal philosophy in Ralph v. Montgomery, a case which arose in the district court of Dubuque County and untimately reached the Iowa Territorial Supreme Court in July, 1839. ${ }^{28}$ The question was whether a Negro slave from Missouri could move to the free territory of Iowa, thereby gaining his freedom, or whether his master could apprehend him and return him to slavery.

${ }^{26} \mathrm{Hill}$ v. Smith and others in Morris (ed.), Iowa Reports, I, 70.

${ }^{27}$ Macy, "Institutional Beginnings," p. 20.

${ }^{28}$ Ralph v. Montgomery in Morris (ed.), Iowa Reports, I, 1-5. 
It is true that the Missouri Compromise of 1820 had theoretically prohibited slavery north of the line of $36^{\circ} 30^{\prime}$, the southern boundary of Missouri. Supposedly this prohibited slavery forever from the remainder of the Louisiana Purchase, of which Iowa Territory was a part. However, Iowa's first territorial legislature had passed an act prohibiting any free Negro from settling in Iowa unless he posted a $\$ 500$ bond for good behavior and a guarantee he would not be a public charge. Whoever either harbored or employed a Negro who had not given such bond was subject to a $\$ 100$ fine. The Negro who failed to give bond could be arrested and hired out to the highest bidder for cash for six months. If a slave had escaped from bondage, any slaveholder might come to Iowa, and with the help of Iowa officers, arrest and take him back. $^{29}$

The case of a Negro slave, Ralph, owned by a Missourian, Montgomery, tested the validity of this statute. Montgomery had given Ralph a written promise that he would secure his freedom upon payment of $\$ 550$. Ralph moved to Dubuque to work in the mines but was unable to earn enough to pay anything on his contract. Montgomery might never have claimed Ralph had not two Virginians offered to return him for $\$ 100$. Montgomery accepted the offer; the two slave catchers came to Iowa, swore out an affidavit that Ralph was a fugitive slave, and procured a court order directing the sheriff to deliver Ralph to them so that they might return him to his master. The Virginians then took Ralph to Bellevue, Iowa, intending to take him to St. Louis on the first steamer. ${ }^{30}$

Before Ralph could be taken from Iowa soil, certain Iowans acted to prevent his removal. Alexander Butterworth, hearing of the arrest, asked Judge Wilson in the federal district court in Dubuque for a writ of habeas corpus to secure Ralph's release from custody. The judge granted it, whereupon the sheriff overtook the slave catchers and returned Ralph to Dubuque. Judge Wilson transferred the case directly to the territorial Supreme Court, which heard it as the

${ }^{29}$ John Dillon, "Address to the Iowa Association of New York," quoted in Stiles, Recollections, p. 20.

${ }^{30}$ Iowa Patriot (Burlington, Iowa), July 18, 1839. 
July term, $1839 .^{31}$

Attorneys for the slave owner, Montgomery, contended that Ralph was an escaped slave, subject to recovery under the statute relative to fugitive slaves, because he had not complied with the agreement to pay for the price of his freedom and was therefore in Iowa Territory without permission. Montgomery's counsel also argued that Iowa Territory did not prohibit slavery and that the Act of 1820 , which prohibited slavery north of $36^{\circ} 30^{\prime}$, was not intended to take effect without further legislative action by the state and territorial legislatures, thus confirming the action of Congress. The lawyers maintained that without such local laws the federal law had no binding effect. ${ }^{32}$

Ralph's attorney contended that Ralph was entitled to his freedom because the Compromise of 1820 prohibited slavery in Iowa. He also argued that Ralph was not a fugitive, since he had been living in the territory with his owner's consent, nor was he subject to Iowa's slavery ruling of 1838 , since he had come into the territory prior to enactment of that law. ${ }^{33}$

Judge Mason rendered the decision after concurring with Associate Justices Joseph Williams and Thomas Wilson. Mason prefaced his remarks with frank admission that perhaps it was not strictly regular for the court to entertain jurisdiction in the case at all. But since it involved an important question which might become an exciting one if it remained unsettled, the court had decided to hear the arguments and to make a decision without intending it as precedent for future practice in that court. ${ }^{34}$ First, Mason ruled that inasmuch as Ralph had come to Iowa with his master's consent, he was not a fugitive, nor could his failure to pay be construed an escape on his part. Mason recognized the obligation of Ralph for the debt, but added that his master could not use non-payment of it as pretext for returning him to slavery. ${ }^{35}$ As for the argument that the Act of 1820 , which prohibited slavery

\footnotetext{
${ }^{31}$ Ibid.

${ }^{32}$ Ralph v. Montgomery in Morris (ed.), Iowa Reports, I, 4.

${ }^{33}$ Ibid., pp. 2-4.

${ }^{34}$ Swisher, "The Case of Ralph," Palimpsest, VII (Feb. 1926), 39.

${ }^{35}$ Ralph v. Montgomery in Morris (ed.), Iowa Reports, I, 6.
} 
north of $36^{\circ} 30^{\prime}$, was meant only as a declaration requiring state or territorial legislation to put it into effect, Mason ruled that the federal law was sufficient to prohibit slavery north of that line and needed no further legislative action to make it effectual. ${ }^{36}$ Finally, Mason ruled that a master who, after passage of the Act of 1820, allowed his slave to become a resident in free territory could not afterward exercise any ownership over him within that territory. This disposed of the contention of the claimant that the Act of 1820 had not provided for forfeiture of slave property found on free soil. ${ }^{37}$ Ralph was therefore given his freedom. The judges had made their decision in the light of human justice rather than according to a strict interpretation of the law.

Another of Chief Justice Mason's contributions to Iowa jurisprudence was the aid he gave the legislature in formulating laws regulating court procedure. On Nov. 21, 1838, the legislature adopted a joint resolution requesting the judges of the Supreme Court to furnish the legislature with bills which would form a proper code of jurisprudence for Iowa and regulate the practice of its courts. ${ }^{38}$ Chief Justice Mason's part in formulating suggested laws concerning judicial procedure is shown in the communication he sent to the House of Representatives. Mason wrote:

In compliance with the resolution passed in the House of Representatives on the 14th inst., I herewith present a bill for regulating criminal procedure in courts of justice. Having been requested by one of the members of that body to draft such a bill, I have been engaged some time in preparing it and had nearly completed it when the resolution was adopted. As it is not convenient at present to consult with the other judges in relations to this matter, and I am informed it is desirable to have the bill in readiness for legislative action as soon as practicable, I have been induced to present it at once for the disposal of the House. ${ }^{39}$

Mason then presented a bill for regulation of the courts relative to criminal procedure. The law as passed by the legislature was entitled "An act defining crimes and punishments." This law constituted the Criminal Code of the Territory. It

${ }^{36}$ Ibid, p. 6.

${ }^{37}$ Iowa Patriot, July 18, 1839.

${ }^{38}$ Journal of the Iowa Council, 1838-1839, Joint Resolution No. 7, Jan. 4, 1839, p. 41.

${ }^{39}$ Journal of Iowa House of Representatives, 1838-1839, p. 197. 
defined in detail each of the crimes punishable under the law, designating the nature and extent of punishments applicable to each case. ${ }^{40}$

The judges also assisted in preparing legislation which provided for probate courts in each county. As finally enacted the law provided for a court of record to be known as the Probate Court, jurisdiction of which extended to all matters relative to estates, testate, and intestate. The court was to convene monthly, with some suitable person within the county to serve as probat judge for a three-year period. ${ }^{41}$

Mason and his judicial associates also introduced a bill which provided that the district courts be given jurisdiction in matters of chancery. Among other less important laws they suggested were those relative to quo warranto, writs of attachment, trespass, replevin, and other civil actions. In fact, many of the most important laws passed by the legislature were penned by Judge Mason. ${ }^{42}$

Besides Mason's services on the Bench, he made another important contribution to the laws of Iowa shortly after the close of his judicial career, when he was largely responsible for drafting the Iowa law code of 1851. A law code, in the proper sense of the term, is a reduction to writing of all the laws, systematically and efficiently arranged by the sanction of legislative authority. The Code of 1851 was the first real codification of Iowa law, although there had been incomplete and imperfect attempts previous to that time. A code of whatever nature soon becomes outdated. Additional laws passed by succeeding sessions of the legislature, together with amendments and repeals of existing laws, make new compilations necessary. By the time Iowa became a state in 1846, there was need for a new compilation, preferably by men learned in the law who were not members of the legislature. Between 1843 and 1856 a great deal of new legislation was enacted. Also, many earlier laws had been repealed or amended, so that it was sometimes difficult to tell whether a given statute was or was not a law. ${ }^{43}$

${ }^{40}$ Laws of the Territory of Iowa, 1838-1839, pp. 142-172.

${ }^{41}$ Ibid., pp. 126-127.

${ }^{42}$ Swisher, "Judiciary of the Territory of Iowa," p. 275.

${ }^{43}$ M'Clain, "Charles Mason-Iowa's First Jurist," p. 605. 
Accordingly a bill was introduced in the legislature on Jan. 7, 1848, for appointment of commissioners to prepare a code of laws for the new state. Two Democrats, Charles Mason and Stephen Hempstead, and a Whig, Samuel Woodward, made up the commission. Mason was chairman, and it is generally understood that he did the principal part of the work of compilation. This necessarily involved a certain amount of editing, which gave him some opportunity to reflect his own views respecting desirable legislation. The Code of 1851 reveals how ready Mason was to innovate upon the established law and strike into new paths. Among other things, he was in step with the most advanced legislation of his time as to the personal and property rights of women. He thought that women possessed the same inherent rights as men. On his own responsibility he recommended the most comprehensive legislation touching the rights of the wife to separate property, and the protection of that right. He was prepared for suffrage for women on the same terms as men. These recommendations were contained in a report that accompanied the Code of $1851 .^{44}$

In the light of Mason's interest in business affairs in general and public transportation in particular, his attitude toward corporations as reflected in the 1851 Code is particularly significant. Dr. William Salter, pioneer Burlington settler, wrote, "For the general incorporation law of the state, we are indebted to the wise and sagacious influence of Charles Mason." ${ }^{45}$ Mason had already been largely responsible for the in the constitution of 1846. It had directed the legislature to first general incorporation law of the state, as provided for provide by "general laws" for the organization of corporations other than for "political or municipal purposes." Consequently in 1847 the first Iowa legislature passed a general incorporation law which gave corporations power to make such regulations as they pleased in relation to management of their business not incompatible with honest and legal purposes, and in other respects invited the creation of corporations. The Code of

${ }^{44}$ Wright, "The Yewell Portrait," p. 165.

${ }^{45}$ Letter of William Salter to Frank Horack, "Some Phases of Corporate Regulation in the State of Iowa," Iowa Journal of History and Politics, II (Oct. 1904), 487. 
1851, edited by Mason, Woodward, and Hempstead did not materially alter the welcoming attitude of 1847 toward corporations. And since much of the Code of 1851 was in substance included in the Iowa Constitution of 1857, Mason's social and economic views found a place in the highest laws of the state. ${ }^{46}$

This survey of Mason's judicial decisions and contributions during his 13 years of government service on the bench suggests that his legal philosophy fitted that described by United States Supreme Court Justice Benjamin Cardozo a century later.. In The Nature of the Judicial Process, Cardozo said that a judge, as the community's interpreter of law and order, must supply omissions in the law, correct its uncertainties, and harmonize it with justice. The Supreme Court Justice called this free decision, whereby the judge sees through transitory particulars and reaches what is permanent behind them. He said that judicial interpretation thus becomes more than ascertainment of the lawmakers' meaning and intention, whose collective will has been declared; the judge supplements the legislative declaration and fills the vacant spaces within statutes. ${ }^{47}$

This judicial philosophy of broad interpretation seems to have been Mason's approach to his legal reasoning. He did not allow himself to be hampered by legal technicalities or phraseology, but cut his way through to conclusions, asserting whatever he believed justice dictated. This does not mean that he ignored legal precedents where they were clearly applicable. It does not mean, either, that he failed to recognize that legal form is designed to protect, not to hamper justice. It simply means that he realized there are times when "new occasions teach new duties and time makes ancient good uncouth," so that social needs demand one settlement rather than another.

Mason was not only a broad interpreter but an innovator

${ }^{46}$ Johnson Brigham, Iowa-Its History and Foremost Citizens (2 vols., Chicago, 1918), I, 225.

${ }^{47}$ Benjamin Cardozo, The Nature of the Judicial Process (New Haven, 1921, pp. 16-17. 
of law. That is, he saw jurisprudence not as dormant but dynamic, so that it must follow the line of historical development, what Cardozo called the method of evolution. It meant that Mason followed one path rather than another to a decision because of his conviction that the one selected led to current justice. This was more than what he personally believed to be right; it was what he reasonably believed some other men of normal intellect and conscience might reasonably look upon as right. So in the end, the principle that was thought to represent the larger and deeper contemporary social interest put its competitors to flight. Thus Mason was never behind others in advanced legal ideas. The 1851 Code reveals how ready he was to innovate upon the established law and to strike into new paths.

Although Mason's judicial philosophy fitted the frontier situation, with its new circumstances not always compatible with established law, it would seem a fallacy to conclude that frontier conditions gave rise to his legal reasoning. Evidently he was never a case book lawyer; his regard for the spirit of justice rather than for the letter of the law was part of his legal outlook before he came West.

It would seem, however, that in Judge Mason the Iowa frontier received the type of person the judicial situation demanded. In 1838, communication between the frontier and the national capital was so slow that there was particular need for territorial judges capable of exercising sound judgment on their own initiatives. For this reason, legal training and experience were less important to judicial service on the frontier than intelligence, energy, a lucid literary style, and adaptable legal philosophy. In this respect Iowa and the nation received in the judicial services of Charles Mason one who deserved well of the republic. 
Copyright of Annals of Iowa is the property of State of Iowa, by \& through the State Historical Society of Iowa and its content may not be copied or emailed to multiple sites or posted to a listserv without the copyright holder's express written permission. However, users may print, download, or email articles for individual use. 